\title{
THE EFFECT OF ORPHANAGE CLIMATE, HOPE, AND GRATITUDE TOWARDS ORPHAN ADOLESCENT IN ORPHANAGES
}

\author{
Khairunnisa Rahmawati ${ }^{1}$, Ilmi Amalia ${ }^{2}$ \\ \{nisniniss@gmail.com,ilmi.amalia@gmail.com\} \\ Faculty of Psychology Universitas Islam Negeri Syarif Hidayatullah Jakarta
}

\begin{abstract}
This study aims to measure the effect of orphanage climate (safety, teaching and learning, relationships, institutional environments) hope, and gratitude (sense of abundance, appreciation for others, simple appreciation) and also gender as demographic variable towards orphan adolescent in orphanages. The total of sample are 259 orphans adolescent in Jakarta Selatan, Tangerang Selatan, and The results showed that there is a significant effect of orphanage climate, hope, gratitude and gender as demographic variable towards orphan adolescent in orphanages. $\mathrm{R}$ square of 0.399 which means that the proportion of variance explained by the resilience of all the independent variables is equal to $39.9 \%$, while $60.1 \%$ is influenced by other variables outside of this research. The test results showed minor hypothesis is safety, hope, and simple appreciation as significant predictors for resilience.
\end{abstract}

Keywords: resilience, social climate, hope, gratitude, orphan, orphanages.

\section{Introduction}

Death and abandonment of parents certainly brought a major change in the lives of orphans and fatherless youth and that will influence the next life. Starting from feelings of loss, unhappy and less can live a life well. According to Nurhidayati \& Chairani [1], the death of one or both parents will make the youth feel lost like loss of attention and compassion, loss of models, loss of security, loss of friends sharing, loss of family integrity and loss of direction. Parents deaths also have psychosocial impacts on adolescents including health issues, physical development, adjustments in work and leisure [2]. Brent, Melhem, Masten, Porta and Payne [3] also suggested that parents' deaths in adolescence, when the child was grown, would have low competence in working, friendship, career planning, and education. Maier and Lachman [4] also suggested in his study that the youth whose parents were gone, in the boys would have more independent impact, while for women would suffer a higher level of depression for the future. The orphanage finally becomes one of the solutions for children and adolescents who do not have one or both parents and relatives and have economic.

Limitations as a place to get guidance, education, decent living places and to meet daily needs. Such studies are Naqshbandi, Sehgal, and Hassan [5], teenagers living in orphanages are mostly due to poverty factors, broken families and family conflicts. However, nowadays, many orphanages are also less well-facilitated. Based on data, the orphan in Indonesia amounted to 
$3,176,642$ [6] whereas Komnas protection of children in 2014 noted that there are 1200 orphanages in Jakarta and 3000 orphanages in Jabodetabek, Thousands of these parlours is estimated to accommodate more than 20 thousand children and only $38 \%$ are worthy of service and have permits [7]. In some literature shows that orphans and orphans raised in orphanages in particular suffer many social, psychological and economic problems [8], [9]. Ibrahim, ElBilsha, El-Gilany and Khater [10] also stated that the common depression occurred in orphans, especially in women. While Yendork and Somhlaba [11] In his research stated that orphans or orphans living in orphanages have higher levels of anxiety than children who still have both parents and do not live in the orphanage. Teenagers living in orphanages are also usually experiencing mental health issues based on DSM criteria, such as panic disorder, agoraphobia, separation anxiety disorder, and others [12].

The youth life of orphaned and orphaned orphanages filled with the dynamics of its own, can affect the youth in terms of ability to endure the circumstances and problems that exist. Therefore, in order to face the various dynamics, it is needed to be a capability called resiliency. Adolescents who have good resilience, they will be able to rise from the severity or the problem and can live better life in the future. Resilience according to Wagnild and Young [13] is the success of being able to cope with change or misfortune, or in other words the ability to rise up and continue life after falling and being stunted. While Connor and Davidson [14] also expresses resilience is a personal quality of one that allows individuals to thrive when faced with difficulties. Resilience according to Wagnild and Young [13] is the success of being able to cope with change or misfortune, or in other words the ability to rise up and continue life after falling and being stunted. While Connor and Davidson [14] also expresses resilience is a personal quality of one that allows individuals to thrive when faced with difficulties. There are factors that can affect the resilience according to the Kumfer [15]. One of these is an external factor that affects the individual's resilience, which is the environment of residence. According to Palacious et.al. [16] stated that the institutional environment of orphanages for orphans could create stability, warmth, and good interaction between fellow members. Other factors related to internal factors include expectations. Hope according to Snyder [17] is a number of abilities to be able to use the way or strategy to achieve the desired goal (agency thinking) along with the motivation skills that have to use the way or strategy (pathway thinking). According to Farran, Salloway and Clark [18]. Hope allows one to continue despite being experiencing difficulties and allowing one to be able to deal with things they know may not be better. Research from the next internal factor is gratitude. Watkins, Woodward, Stone \& Kolts [19] states that gratitude is a tendency to experience feelings of thankfulness as an appreciation for the kindness received. Another factor affecting the resilience of one's self is gender. The research conducted by Sun and Steward [20] states that there are no other things and interactions between gender and age against resiliency. Meanwhile, according to research conducted [21] [22] stated that there is no gender influence on resiliency. The difference in such research is the reason why researchers want to examine gender demographic variables.

The above explanation generally suggests that the climate of orphanages, hopes, gratitude, and gender can affect the resilience of teenagers and is important to note. Nevertheless, there has been no research to see the shared contributions about the variables that make researchers interested in studying more deeply. 


\section{Method}

\subsection{Participant}

In this research the total samples amounted to 259 people aged 13-18 years living in an orphanage located in the area of South Jakarta, Depok, and Tanggerang Selatan.

\subsection{Measuring Instrument}

In this study, the authors used a scale of Resilience scale (RS) developed [13]. This scale consists of 25 item statements that reflect 5 components of resiliency including the meaningful life, perseverance, self-reliance, equnimity, and existential alonenes. Comprehensive school climate inventory (CSCI) scale developed by Cohen [23]. This scale consists of 29 items of statement reflecting 4 social climate components including safety, teaching and learning, relationships, and institutional environment. State of Hope Scale belong to Snyder et.al. [24] that has been adapted previously. State Hope Scale consists of two components such as pathway thinking and agency thinking. The entire item contained in this scale is as many as 8 items. Gratitude Resentment Appreciation Test-Short form (GRAT-short form) developed by Watkins et al. [22]. The measuring instrument consists of 3 pre-adapted dimensions. The entire item contained in this scale is 17 items.

\section{Results}

There is a significant influence of safety, relationships, Teaching and learning, institutional environment, Hope, sense of Abundance, Appreciation For others, Simple appreciation, and the gender of resilience. The proportion of variances of resiliency that can be explained by all independent variables is $39.9 \%$, while the remaining $60.1 \%$ is affected by other variables outside of this study. In measuring resiliency, of course there are many other factors that can affect other than an orphanage climate, hope and gratitude.

\section{Discussion}

Based on the results of the research shows that overall there is a significant influence of orphanage climate variables, hopes, and gratitude for the adolescent orphan and orphan resilience in the orphanage. Based on a regression coefficient, only the safety dimension in the orphanage climate variable, hope, and simple appreciation in a variable of gratitude that significantly affects the youth's orphans and orphans' resilience Orphans in the orphanage. Safety in the climate variables of the orphanage is a rule and norm that must be adhered to, as well as security in physical and social-emotional [26]. In this research safety affects the resilience of orphans and orphans in orphanages most likely due to the physical and emotional security factors that are important role when they are in the orphanage making them feel safe when staying there. This is in line with the research conducted by Enthoven [27] stating that safety is contributing to the resilience of the youth, and it is explained that one of the factors that There are clear rules, expressing confidence, mutual understanding among fellow Members, and so forth. In the hierarchy theory of needs of Abraham Maslow is also mentioned that safety or need for safety is the second fundamental necessity after physiological needs. 
The needs of it include physical security, protection, freedom from threatening forces, such as fear and anxiety, and also the need for regularity and tranquility [28]. If it is associated with this research, basically orphans and orphans in orphanages do need a sense of safety in themselves in the case of those who have lost one or both parents and Experiencing limited circumstances while staying in an orphanage. With the fulfillment of these needs, it can automatically make them feel safer in living a life that can indirectly affect the resilience of the self. One way to create safety is to apply the norm and clear rules in the place where they live is in the orphanage such as the research mentioned above. Whereas when one does not get or not fulfill the needs of the safety, then they will likely experience what is Maslow [28] say that is basic anxiety (basic Anxiety).

Based on research in schools, without the supporting norms and rules, the relationships between students are more likely to experience the violence of others, acts of law discipline, and with high attendance, and decreased academic performance [29]. Similarly, if it is assumed by the circumstances of an orphanage that has a less supportive regulation, then the possibility of the above may occur. However, in this research, safety is able to provide a significant positive influence on resilience and signifies that there are obvious norms and rules that will cause good physical and psychic security. So it will make someone increasingly resilien. In the climate variables of this orphanage, teaching and learning, relationships, and institutional environment do not present significant results. When viewed from the psychological dynamics, orphans and orphans in orphanages may realize that the social condition of their environment does not entirely affect the resilience of the self. Starting from the state of the teaching and teaching process that may be less optimal, the relationship between others is well-established but less supportive of each other, and the environment around different orphanages are less well-facilitated and Limited-purpose. Such circumstances they received and lived in the orphanage, so they were accustomed to the situation by accepting all its shortcomings and limitations. Another case with the safety dimension that has been explained about its effect on resilience, which signifies that the children who live there need security in themselves and also there is already a clear rule and norm in the orphanage about safety in both physical, social, and emotional terms. A significant second dimension to resiliency is hope, the higher the expectation, the higher the resilience in the person, and vice versa. This is in line in a variety of studies on expectations that influence the resiliency [30]. Expectations also have the most significant proportion of variants among other variables. This can happen because basically they have lost one or both parents in addition to living in an orphanage that has limitations when they live there. So when they are in the situation, the hope of a better future becomes one of the most influential things in their self-sufficient resilience. Like the research conducted by Collins [31] stating that people who have high expectations, when often faced with negative events in life, will have a higher resilience than those who Have high hopes and are more often faced with positive events in life.

As Kumfer [15] said that hope is one of the predictors of internal factors on the resilience of one's self. Hope also relates to the goal as a final goal. Hope to be able to reach the desired goal and to be a successful person in the day, become one of the keys for the orphan and orphans in the orphanage to continue to endure every circumstance in his life. With hope and the final goal to be achieved, it allows them to focus more on what they want to achieve and enable them to become more passionate in their daily activities and to learn to teach, So that they can improve their ability to cope with difficulties that can achieve their goals as successful people. Lastly is simple appreciation on a variable of gratitude also has a significant influence in this research. Simple Appreciation is an appreciation of the simple things in life. When 
viewed from the psychological dynamics, this variable is significant compared to the others because the orphans and orphans in the orphanage easier feel the appreciation of the simple things in him. They tend to appreciate what they experience in life, as they are indeed accustomed to living modestly when living in orphanages with all its limitations. Orphanages do essentially teach them to be able to live what it is with simplicity and limitation, teaching them to be able to appreciate what they receive in life by continuing to be grateful in living the life Albeit in many shortcomings encountered. Therefore, the experience of positive emotions such as gratitude, can help build personal resources such as resiliency that helps individuals to continue to be grateful when dealing with the bad thing [25]. And most importantly, gratitude can make a more positive thought from the negative events [25]. So it can be said in this study that simple appreciation has a positive influence on the resilience of the inside of them. While the sense of abundance and appreciation for others (appreciation for the role of others) in this variable of gratitude does not get a significant result of the resilience. It is not in line with research conducted by Ayudia and Solicha [33], which found that sense of Abundance has a significant influence on resilience. However, the research also goes along with Ayudia and Solicha [33] research, which also mentions that appreciation for others has no significant effect on resiliency. Not signified Sense of Abundance and a Appreciation for Others in this study, if viewed from its psychological dynamics, may be due to the orphan and orphaned teenagers in the orphanage feel their lives are all-fitting and yet to have enough for them to live in a confined orphanage. And they don't feel too much about other people's role in their lives, only certain people can understand their situation and condition. So it can be said in this study, it is a thing that does not affect the resilience within them. Lastly, the gender of the study has no significant effect on resilience. This is contrary to the research conducted by Sun and Steward [20] that there is an influence and interaction between gender and age against resilience. However, this study was also supported by previous studies [34], [22] that there was no significant influence between gender and research. This may be due to the young orphan and orphans of both men and women who are in the orphanage have a good relationship between caregivers and other orphanage members, so there is no difference in applying resiliency themselves. Such research from Broderick and Korteland; Frydenberg and Lewis; Hampel and Petermann [24] states that both men and women are reported to have a positive relationship between their parents, teachers, communities and peers, therefore there is no gender difference. affect their resiliency.

\section{References}

[1] Nurhidayati \& Chairani, L. Makna kematian orangtua bagi remaja (studi fenomenologi pada remaja pasca kematian orangtua). Jurnal Psikologi, 10 (1), 41-48. (2014)

[2] Raza, S., Adil, A., \& Ghayas, S. Impact of parental death on adolescents' psychosocial functioning. Journal of Psychosocial Research, 3 (1), 1-11 (2008)

[3] Brent, D.A. Melhem, N.M., Masten, A.S., \& Porta, G. Longitudinal effects of parental bereavement on adolescent developmental competence. Journal clinical child adolescent, 41 (6), 778-791. (2012)

[4] Maiyer, E.H., \& Lachman, E. Consequences of early parental loss and separation for health and wellbeing in midlife. International Journal of Behavioral Development, 24 (2), 183-189. (2000) 
[5] Naqsbandi, M.M., Sehgal, R., Hassan, F.U. Orphans in orphanages of Kashmir and their Psychological problems. International NGO Academic Journals, 7 (3), 55-63. (2012)

[6] Aditia maruli. Berapa jumlah anak yatim di indonesia ? diambil tanggal 4 juni 2016 dari www.antaranews.com (2013)

[7] Isnaini. Ribuan panti asuhan ilegal. Diambil tanggal 4 Juni 2016 dari www.okezone.com Jameel, S.N., Shah, S.A., \& Ganaie, S.A. (2015). Perceived social support and resilience among orphans: a systematic review. The International Journal of Indian Psychology, 3 (1), 77-82. (2014)

[8] Korantang C., Simons, B. Residents' perception of the built environment quality in an orphanage. Advances in applied science research. 3 (1), 19-30. (2012)

[9] Hall, D. Sompendium of select resilience and related measurement for children and youth. Journal of child and family partnership, 1-19. (2010)

[10] Ibrahim, A., El-Bilsha, M.A., El-Gilany, A., \& Khater, M. Prevalence and predictors of depression among orphans in Dakahlia's orphanages, Egypt. International Journal of Collaborative Research on Internal Medicine \& Public Health , 4 (12), 20362043. (2012)

[11] Yendork, J.S., \& Somhlaba, N.Z. Stress, coping and quality of life: An exploratory study of the psychological well-being of Ghanaian orphans placed in orphanages. Journal Children and Youth Services, 26-37. (2014)

[12] Bhat, A.A., Rahman, S., \& Bhat, N.M. Mental health issues in institutionalized adolescent orphans. The International Journal of Indian Psychology, 3 (1), 1-21. (2015)

[13] Wagnild, G.M., \& Young, H.M. Develompental and psychometric evaluation of the resilience scale. Journal of Nursing Measurement, 165-178. (1993)

[14] Connor, K.M., \& Davidson, J.R.T. Development of a new resilience scale: the connordavidson resilience scale (SD-RISK). Journal of Depression and Anxety, 76-82. (2003)

[15] Kumfer, K. (2002). Chapter nine: Factors and process contributing to resilience: the resilience framework dalam Glantz M.D., \& Jhonson J.L (ed). Resilience and Development Positif Life Adaptaton (hal. 179215). Newyork: Kluwer academic plubisher. (2002)

[16] Palacious, J., Ijzendoorn, M., Barke, E., Gunnar, M., Vorria, P., Mccall, R., Mare, L, Bakermans, M.J., Dobrova-krol, N., Juffer, F. Children in institutional care: delayed development and resilience. Journal of child development. 91-101. (2011)

[17] Lopez, S.J., Snyder, C.R.,\& Pedrotti, J.T. Hope: many definitions,many measures. Dalam Lopez. \&. Snyder (ed). Positive psychological assessment: A handbook of models and measures. (91-106). Washington: American Psychological Association. (2004)

[18] Weil, C. M. Exploring hope in patients with end stage renal disease on chronic hemodialysis. Nephrology Nursing Journal, 27(2), 219-224. (2000)

[19] Watkins, P.C., Woodward, K., Stone, T., Kolts, R.L. Gratitude and happiness: development of a measure of gratitude, and relationships with subjective well-being. Social behaviour and personality, 31(5), 431-452. (2003)

[20] Sun, J., Stepwart, D. Age and gender effects on resilience in children and adolescents. International Journal of Mental Health Promotion, 9(4), 16-25. (2012)

[21] Splan R.K., Brooks, R.M., Porr, S \& Broyles, T.W. Resiliency and achievement goal orientation among agricultural students. NACTA journal, 31-38. (2011)

[22] Sreehari, R \& Nair A.R. Age and gender difference on resilience among school going adolescents. Global journal for research analysis, 4(7), 195-196. (2015) 
[23] Cohen, Mccabe, Michelli, \& Pickeral. School climate research summary. 1(1), 1-16. (2010)

[24] Snyder, C.R., Cheavens, J., \& Michael, S,T. Hoping. Dalam C. Snyder (ed). Coping: the psychology of what works (hal. 205-231). Newyork: Oxford Unversity Press (1999)

[25] Watkins, P.C., Grim, D.L., \& Kolts, R. Counting your blessings: positive memories among grateful persons. Currect psychology, 23, 52-67. Weil, C. M. (2000). Exploring hope in patients with end stage renal disease on chronic hemodialysis. Nephrology Nursing Journal, 27(2), 219-224. (2004)

[26] O'Brennan., Bradshaw, C.Important of school climate. National Education Assosiation. 1-4. (2013)

[27] Enthoven, M.E.E. The ability to bounce beyond: the contribution of the school environment to the resilience of dutch urban middle-adolescents from a low socioeconomic background. Dissertation: University of Pretoria. 1-252. (2007)

[28] Feist, J \& Feist, G.J. Teori kepribadian Edisi 7. Jakarta: Salemba Humanika. (2010)

[29] Thapa, A., Cohen, J., D’Alessandro, A.H., \& Guffey, S. School climate research summary. School Climate Crief Number 3, 1-21. (2012)

[30] Pienaar, A., Swanepoel, Z., Rensburg, H., Heunis, C. A qualitative exploration of resilience in preadolescent AIDS orphans living in a residential care facility. Journal of Social Aspects of HIV/AIDS, 8 (3), 128-137. (2011)

[31] Collin, A.B. Life experiences and resilience in college students: a relationship influenced by hope and mindfulness. Dissertation: Texas A\&M University.1141. (2009)

[32] Watkins, P.C., Grim, D.L., \& Kolts, R. Counting your blessings: positive memories among grateful persons. Currect psychology, 23, 52-67. Weil, C. M. (2000). Exploring hope in patients with end stage renal disease on chronic hemodialysis. Nephrology Nursing Journal, 27(2), 219-224. (2004)

[33] Ayudia, F.V.K., \& Solicha. Resiliensi penyandang tuna daksa: pengaruh dukungan sosial dan gratitude dalam membentuk individu yang resilien. TAZKIYA journal of psychology. 19 (2), 151-170. (2014)

[34] Keshtegarl, M., \& Jenaabadi. Relationship among emotional intelligence, spiritual intelligence and resilience of student at University of Zabol. International journal of clinical medicine, 759-768. (2015)

[35] Abdi, N \& Asadi, L. M. (2011). Standardization of three hope scale, as possible measure at the end of life, in Iranian population. Iranan Journal of Cancer Prevention, 14(2), 71-77.

[36] Capp, G., Sullivan, K., \& Gilreath, T.D. School climate and resilience: an exploration of latent patterns of student perception, 1-42.(2011)

[37] Cazan, A.M \& Dumitrescu, S.A. (2015). Exploring the relationship between adolescent resilience, selfperception and locus of control. Romanian Journal of Experimental Applied Psychology, 7 (1), 283-286. (2015)

[38] Chung, Feng. H. (2008). Resiliency and character strengths among college students. Dissertation: The university of Arizona. 1-183. Ciarrochi, J., Heaaven, P., Davies, F. (2007). The impact of hope, self-esteem, and attributional style on adolescents' school grades and emotional well-being: A longitudinal study. Journal of Research in Personality, 41(2007), 1161-1178. (2008)

[39] Clifford, M., Menon R., Gangi, T., Condon, C., \& Hornung, K.Measuring school climate for gauging principal performance. American Institute for Research. 1-20 (2012) 
[40] Emmons, R. A., \& Crumpler, C. A. Gratitude as a human strength: Appraising the evidence. Journal of Social and Clinical Psychology, 19(1), 56-69. (2002)

[41] Fayombo, G. Student-related variables as predictors of academic achievement among some undergraduate psychology students in Barbados. Journal of Education Review, 280-289 (2011)

[42] Gomez, M., Vincent, A., Toussaint, L. (2013. Correlates of resilience in adolescents and adult. International Journal of Clinical Psychiatry and Mental Health, 1, 18-23.

[43] Grotberg. (1995). A guide to promoting resilience in children: strengthening the human spirit. Journal of Early Childhood Development: Practice and Reflections, 8, 139

[44] Luthar, S.S., Cicchetti.D.,\& Bronwyn.B. The construct of resilience: critcal evaluation and guidlines for futuru work. Child Development, 71 (3), 543-562 (2000)

[45] Mccullough, M. E., Kilpatrick, S. D., Emmons, R. A., \& Larson, D. B. (2001). Is gratitude a moral affect? Journal of Psychology, 127(2), 249-266. Mccullough, M.E., Tsang, J.A., Emmons, R.A. (2002). Grateful Disposition: A Conceptual and Empirical Topography. Journal of Personality and Social Psychology, 82 (1), 112-117. (2001)

[46] Mehrotra, S., Chaddha, U. A co relational study of protective factors, resilience and self esteem in pre medical dropouts. International Journal of Humanities and Social Science Invention, 2 (9), 103-106. (2013)

[47] Nurhidayati \& Chairani, L. Makna kematian orangtua bagi remaja (studi fenomenologi pada remaja pasca kematian orangtua). Jurnal Psikologi, 10 (1), 41-48. (2014)

[48] Wood, A., Froh, J., Geraghty, A. (2010). Gratitude and well-being: A review and theoretical integration. Journal of Clinical Psychology Review, 30, 890-905. Doi:10.1016/j.cpr.2010.03.005.

[49] Reivich, K., \& Shatte, A. The resilience factor: 7 key to finding your inner strength and overcome life's hurdles. New York: Broadway Books.(2001)

[50] Rutter, M. Annual Research Review: Resilience - clinical. Journal of Child Psychology and Psychiatry, 54 (4), 474-487. (2013)

[51] Kirmani, M.N., Sharma, P., Anas, M., \& Sanam, R.. Hope, resilience and subjective weelbeing among collage going adolescent girls. wooInternational Journal of Humanities \& Social Science Studies 2(1), 262-270 (2015)

[52] Hurlock, E.B.. Psikologi perkembangan edisi kelima. Istiwidayanti, Soedjarwo (Terj). Jakarta: Erlangga (1980)

[53] Peterson dan Seligman. 2004. Section 3 Gratitude. Dalam Peterson, C., \& Seligman, M.E.P (ed). Character strength and virtues. 553-568. Newyork: Oxford university press. (2004)

[54] Peye, M.D., \& Pidgeon, A. (2013). An investigation of the relationship between resilience, mindfulness, and academic self-efficacy. Journal of Social Sciences, 1 (6), $1-4(2013)$

[55] Snyder, C.R., Rand K.L., Sigmon, D.R. Hope theory: a member of the positive psychology family. Dalam Lopez, S.J, \& Snyder, C.R (ed). Handbook of Positive Psychology (hal. 1-848). Newyork: Oxford University Press, Inc. (2002)

[56] Mccullough, M.E., Tsang, J.A., Emmons, R.A. Grateful Disposition: A Conceptual and Empirical Topography. Journal of Personality and Social Psychology, 82 (1), 112117. (2002) 